\title{
DE-STALINISATION OF SOVIET FOREIGN POLICY TOWARDS INDONESIA: REVIEWING THE FEASIBILITY OF THE THEORY OF FOREIGN POLICY CHANGE
}

\author{
Radityo Dharmaputra \\ Universitas Airlangga, Surabaya, Indonesia
}

\begin{abstract}
This paper re-evaluates the changing policies of the Soviet Union towards Indonesia during the era of Joseph Stalin and Nikita Khrushchev, by applying the contemporary theory of foreign policy change. After discussing the debates revolving around the theory of foreign policy change from Gustavsson and Hermann, this paper contends that if there were any changes, then the causal factors would likely be the interplay between the domestic factors and international factors, as Putnam has argued. This finding enhances the understanding that the domestic de-Stalinisation process undergone during Khrushchev's era was not the only factor that might affect Soviet's foreign policy. By using the case of Indonesia as the representation of the developing countries, the author shows that both sets of factors affected the changing policy. However, author also found that the systemic condition of the Cold War, namely the contestation between the US and USSR, was more influential than the domestic condition. This paper contributes to the deeper understanding of Soviet-Indonesia relations, the effect of domestic de-Stalinisation to foreign policy, and the feasibility of applying current theory of foreign policy change to an historical case.
\end{abstract}

Key words: de-Stalinisation, Soviet foreign policy, theory of foreign policy change, Indonesia, domestic factors, international factors

The death of Stalin in 1953 brought an abrupt shift in USSR, particularly in the domestic realm. As Tucker had observed, this de-Stalinisation process had started immediately after Stalin's death, extending from the Beria's denunciation of the use of torture, the reorganisation of party's structure, to the contestation of leadership between BeriaMalenkov and Khrushchev-Bulganin faction [Tucker 1957]. According to Pospielovsky, there was a "law of accumulating hatred" which happened to every Soviet leader, except Lenin, and this "law" forced Khrushchev to distance himself from Stalin's name, as part of the de-Stalinisation [Pospielovsky 1968].

Accordingly, this domestic upheaval could affect the conduct of Soviet foreign policy. The debate had argued whether the domestic de-Stalinisation prompted the change in foreign policy. Armstrong argued that one of the main sources of Soviet foreign policy was their domestic politics and during the period of de-Stalinisation several foreign policies were shifted [Armstrong 1965]. On the other hand, Gati discussed that while several changes might be detected, the changes had never been part of a long strategy [Gati 1980]. Gati argued that the domestic de-Stalinisation had no effect in the conduct of Soviet foreign policy, as the Soviet leader apparently continued to depend on the Stalin's legacy of assertiveness and accommodation [Gati 1980: 663].

This paper seeks to clarify the relations between Soviet domestic politics and their foreign policy choices, especially during the period of de-Stalinisation. To comprehend 
this relation, this paper focuses its analysis on the Soviet policy towards the developing countries, which was exemplified by the Non-Aligned Movement. The main case in this paper is Indonesia, because as Pauker said, Indonesia was one of the biggest recipient of the Soviet aid during the era of Khrushchev [Pauker 1962]. Boden also examined that Soviet had given Indonesia more resources than any developing countries in the world, with the exception of Egypt [Boden 2008: 110]. This paper contends that the Indonesian case could highlight the dilemmatic question of whether there was any change in the Soviet foreign policy, and whether the change was related only to the domestic restructuring or the other factors. By doing so, this paper also reviews the feasibility of the contemporary theory of foreign policy change in analysing some historical cases.

Elaborating this goal, this paper is divided into four parts. The first part elaborates the theoretical framework about change and stability in foreign policy. The second part compares Soviet foreign policy towards Indonesia during the era of Stalin and Khrushchev, and elaborate the question of whether there was stability or change. The third part elaborates the relations between the domestic restructuring during the de-Stalinisation, the international factors, and the changing/continuing Soviet foreign policy towards Indonesia.

\section{CHANGE AND CONTINUITY IN FOREIGN POLICY: A THEORETICAL CONSIDERATION}

The study of changes in foreign policy, especially during Cold War, was underdeveloped. According to Gustavsson, the study of foreign policy in the Cold War tended to marginalise studies regarding changes while focusing on stability [Gustavsson 1999]. This lack of study about foreign policy change during the Cold War could highlight the importance of this paper, which aims to elaborate the change in Soviet foreign policy.

After the Cold War, one of the most influential work on foreign policy change was Charles Hermann's work. Hermann identified several types of change, from the lowest level of adjustment to the highest level of international orientation change [Hermann 1990]. Based on this typology, Eidenfalk offered 7 levels of change, consists of (i) stability, in which there was no change; (ii) intensification/reduction, in which there was a quantitative change, exemplified by the addition or subtraction of foreign aid; (iii) refinement, in which there was a qualitative change of instrument, but the old instrument was still in use as in the use of technical assistance, but the foreign aid is still being done; (iv) reform, which is a change in the qualitative instrument, to replace the entire instrument previously used in foreign policy; (v) redirection, which is the change of purpose but with a combination of the long goal with a new purpose; (vi) reorientation, which changes the overall purpose by replacing the previous goal; and (vii) restructuring, which is a substantial change in almost all areas and issues involved and have an impact on many actors [Eidenfalk 2009].

Gustavsson has initiated the development of Hermann's theory [Gustavsson 1999]. He elaborated several theories, from Hermann to Rosati, but his theory was more connected to Hermann's [Gustavsson 1999]. As the figure from Gustavsson showed, his theory elaborated Hermann's typology while creating a clearer argument. 


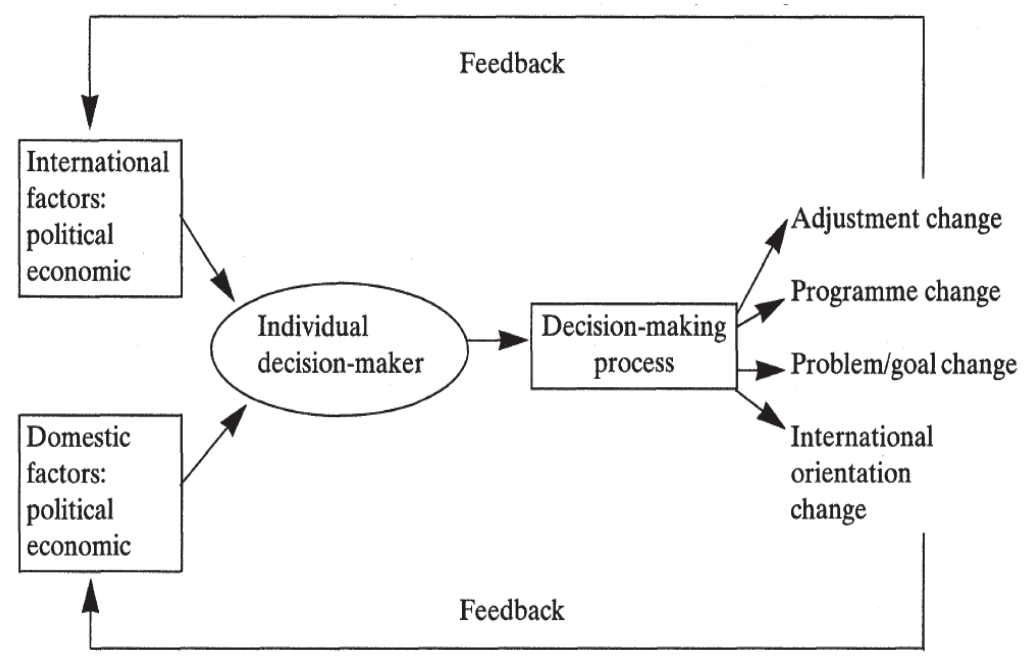

Fig. 1. The Causal Dinamics of Foreign Policy Change Sources: [Gustavsson 1999: 85]

It can be seen that Gustavsson emphasised the existence of two major factors, namely the international and domestic factors [Gustavsson 1999]. International factors can be divided into political aspects, which include the power relations and military aspects, as well as economic aspects, which include cross-border transactions and institutional conditions. Domestic factors can also be divided into the political aspects, which include the support of voters, political parties, and societal actors who had views on foreign policy, and the economic aspects, which include the variable of Gross Domestic Products (GDP), the condition of inflation, unemployment, and institutional conditions (labour relations and market).

Using Gustavsson's theory, this paper elaborates the domestic conditions of the USSR during the de-Stalinisation process, to investigate whether or not the domestic restructuring influenced the Soviet policy towards Indonesia. However, as the theory suggested, the international factors could have played considerable influence. The interplay between the domestic factors and the international factors, as suggested by the "twolevel games" from Putnam also be observed in the proceeding part [Putnam 1988].

\section{USSR FOREIGN POLICY TOWARDS INDONESIA: BEFORE AND AFTER 1953}

\section{Soviet-Indonesia Relation before 1953}

The relations between USSR and Indonesia was understudied, even though, as Pauker and Boden stated, Indonesia was one of the biggest recipient of Soviet's aid during 1945 to 1965 [Pauker 1962; Boden 2008]. Singh's thesis (1986) was probably one of the most detailed account of the relation between USSR and Indonesia [Singh 1986]. Combined with Efimova's works on the recently released archives regarding the initial relation between USSR and Indonesia, their works would be the main sources of this paper's attempts to comprehend the nature of this relation [Efimova 1998; 2001]. 
As Singh argued, the development of Soviet-Indonesia relation could be divided into several timelines [Singh 1986]. In this paper, the timeline is divided into pre-1953, before the death of Stalin, and after 1953. After Indonesian independence of 1945 and towards the end of Stalin's era in 1953, Singh observed the dynamics of relationship. He argued that, fundamentally, Stalin and USSR did not have a major interest in the region [Singh 1986: 154]. Therefore, the relation was very vibrant, fluctuating from the Soviet ignorance towards the Indonesian nationalist movement in the early years of independence to the acceptance of the August Independence, after the telegram from Indonesian president's Soekarno to Stalin on the anniversary of the October Revolutions and the reciprocal message from Moscow supporting the Indonesian independence [Singh 1986: 88].

Singh argued that this change in Moscow's view was caused by the willingness to play a bigger role in Southeast Asia. Especially, since Moscow could not influence the event in Indo-China because of the presence of France (which had substantial number of communist in the government) [Singh 1986]. Therefore, Singh had considered that Moscow wanted to control the former Dutch colonies because of the considerable weaknesses of the Communist Party in Netherlands. However, as Efimova had observed during her archival research, the USSR apparently did not move quick enough to acknowledge Indonesian independence [Efimova 1998]. The initial request, albeit indirectly, for the recognition of Indonesian independence was made during the Interasian conference in New Delhi, in 1947. As Efimova had stated, Indonesian delegation, led by Prime Minister and Minister of Foreign Affairs Sutan Sjahrir, had unofficial meetings with the Soviet delegation [Efimova 1998: 186]. Nevertheless, Efimova suggested that the USSR had to consider the international law and the geopolitical realities in Europe and Asia before making a decision on the Indonesian request [Efimova 1998]. As the geopolitical event proceed and the Dutch had reoccupied Indonesia during 1945 to 1949, the archive suggested that the USSR had considered acknowledging Indonesian independence of 1945, even though it would provoke the US. Related to this argument, Singh stated that even though the USSR had raised the issue of "Indonesian question" in the United Nations, they did so because the British had questioned the reluctance of the Soviet to leave Iran [Singh 1986: 93].

The above conditions during the early years of Indonesian independence revealed the dilemma faced by the USSR. In one hand, the USSR wanted to expand the sphere of influence to Western Europe, had failed to do that, and instead tried to exercise their influence into the former Dutch colonies in Southeast Asia. On the other hand, the initial goals and concerns of the USSR was mainly in Europe, not in Asia. As Singh had observed, only the action of the British, which then prompted the USSR to raise the Indonesian issue in the UN. The willingness to portray themselves as the moral power of the anti-colonialism, compared to the US, was also considered by Singh as the main reason of USSR policy [Singh 1986: 93]. In this sense, the initial concerns regarding Indonesia during the Stalin's era was not about Indonesia or the Asia, but about the USSR's relations with Western Europe and United States.

During the later days of Stalin's era, from 1947 to 1953, there were some developments regarding the Soviet-Indonesian relations. As Singh argued, the emergence 
of Zhdanov doctrine could be considered as the beginning of the good relationship between Indonesia and USSR, because Indonesia was considered a member of the Sovietled camp [Singh 1986: 107]. Efimova observed that only the outbreak of Madiun Rebellion in 1948, in which the Communist Party of Indonesia (PKI) was deeply involved, have caused the worsening of the relation [Efimova 1998]. While the USSR had already preparing for the opening of consul in Indonesia and the Indonesian Republic had expressed its gratitude towards Soviet's acknowledgement, the event of communist rebellion in Madiun had left the Indonesian government with no choice but to cancel the ratification of the agreement with the USSR. Whether or not this rebellion instigated by the Soviet was unclear, even though, as Singh had presented, Moscow had expressed their support of the communist rebellion [Singh 1986: 125]. Nevertheless, it prompted the gradual chilling of relations between Moscow and Jakarta, which was complicated by the US support towards Indonesia following the failed communist rebellion in Madiun.

The following years from 1948 to 1952 was characterised by a duality of relationship between USSR and Indonesia. Drawing from Singh and Efimova, this paper suggests that the duality could be seen as suspiciousness towards Indonesian government on one hand, and the criticism to the Dutch's aggression to Indonesia in 1948-1949 on the other hand. This duality could be seen when the US acknowledged Indonesian independence in December 1949, just one day after the initial independence, while the USSR had just recognised Indonesia in January 1950. This delay could be seen as the reluctance to support the Soekarno-Hatta government, which was deemed as the liberal puppet. This duality, according to Singh, could be outlined from 1950 into 1952, in which the presence of the Federal Government of Indonesia (until August 1950), and the succession of pro-Western leader of the government of Indonesia, was seen by Moscow as the signs of Indonesian tendency towards the Western blocs.

As Singh had argued, only the change in Stalin's foreign policy after 1952 could change the condition of Soviet-Indonesia relation [Singh 1986: 147]. Indeed, as events proceed during 1952 to 1953 , the gradual restoration of the Soviet-Indonesia relations had happened, began by the emergence of pro-communist leader in Indonesia, was further enhanced by the willingness of the USSR to provide aid to the former colonies countries, and was highlighted by the decision of Indonesian government under Prime Minister Wilopo to establish Indonesian embassy in Moscow. Even though this plan was cancelled due to the lack of funds, Singh argued that the friendly gesture was well received in Moscow [Singh 1986: 154].

It is sufficed to say that during the era of Stalin, even though the dynamics had been so volatile, in the later years the relation between Soviet and Indonesia was beginning to improve. Related to the theoretical framework of foreign policy change, this period had shown that the presence of international factors was more influential than the domestic factors. The Soviet foreign policy was influenced more by the action of other countries such as Netherlands, British, and the United States, rather than the domestic considerations. Obviously, the presence of Stalin and the absence of domestic turmoil in USSR should be taken into considerations. Between 1945 to 1952, the control of the Soviet government was in Stalin's hand, and the foreign policy of the USSR was mainly Eurocentric. However, it should be noted that the recuperation of the Soviet- 
Indonesia relations had already under way during the later years of Stalin. Stalin had even changed his policy to recognise the Republic of the United States of Indonesia (RUSI) in January 25, 1950, while previously (until January 19) refused to recognise RUSI and criticise RUSI as the bargain between feudals and colonialists [Efimova 2001]. It is therefore quite possible that the Soviet policy towards Indonesia after 1953 was a continuation of the Stalin's policy, albeit in some different methods.

\section{Soviet-Indonesia Relations after 1953}

Stalin's death prompted another dynamic for the Soviet-Indonesia relations. Several scholars had argued that the changing policies of the USSR was in motion after the changing domestic circumstances. This part of the paper evaluates this claim, and analyses the change that happened and the possible cause of it.

After the emergence of Nikita Khrushchev as the new leader of the USSR, scholar had argued that there was some revision of Soviet foreign policy, especially regarding the developing countries in the Southeast Asia. Williams had argued that during the early years of Khrushchev, he tried to build stronger ties with the Third World country in Southeast Asia, by visiting Burma and Indonesian in 1960 [Williams 1991]. Horn had even claimed, the visiting tour by Khrushchev and Bulganin in 1955 (to Burma) and in 1960 (Burma and Indonesia) was designed to be the first stepping-stones towards closer relations [Horn 1975]. Certainly, the relations between Jakarta and Moscow was expanding. As Horn had observed, the USSR had given many resources to Indonesia, from economic aid to create steel mills and oceanographic research institutes to military assistance in the forms of aircraft (MIG-21s and TU-16s) and submarines [Horn 1975: 659]. Pauker confirmed the existence of this aid, when he explained how Indonesian president Soekarno visited Moscow in 1956, and the Indonesian Army General A.H. Nasution visited Moscow in 1961, to conclude an arms deal [Pauker 1961].

This arms deal, based on the communique regarding Nasution's visit, was related to the ongoing crisis in West Irian. This crisis marked another Soviet policy towards Indonesia. Derkach's research regarding Soviet policy towards Indonesian action in West Irian and Malaysia was important, in a sense that these two cases highlighted the dilemma faced by the USSR [Derkach 1965]. In the case of West Irian, Derkach reported that the USSR was fully supported of the Indonesian claim, because they saw the crisis as a conflict between the Dutch (the former colonial powers) and Indonesia (the newly independent states). On the other hand, Soekarno's policy of "Konfrontasi" with Malaysia was considered as a conflict between new states. The full support from the USSR for Indonesian claim in West Irian was nowhere near the hesitancy to support Indonesia in the Indo-Malaysian conflict. The case of West Irian was the most important turning point, related to the development of Soviet-Indonesia relations and the causal factors behind it. The endgame in West Irian, decided peacefully through the people's referendum in 1969 (regardless of the controversies surrounding this process) was considered the turning points in Soviet policy towards Indonesia. Singh even claimed that, had the Indonesian government acted in accordance with the Soviet's preference, it was highly possible that the relations between Soviet and Indonesia would continue to intensify [Singh 1986: 204]. 
Nevertheless, generally, Soviet policy towards Indonesia during the period after Stalin's death (since 1953 up until 1964) was considered the highest point in the history of relationship between the two countries. The amount of economic and military aid, combined with the political support towards the Indonesian government was unprecedented. However, the problem remains. Is this condition could be considered as foreign policy change? If so, what is the main causal factors? The domestic variables or the international aspects? The next section of this paper was dedicated to explore this problem.

\section{CHANGE IN SOVIET FOREIGN POLICY TOWARDS INDONESIA: THE SUPERIORITY OF INTERNATIONAL FACTORS}

The first issue that is clarified in this section is the concept of change. The previous section had shown differences between Stalin's foreign policy towards Indonesia and the foreign policy of the de-Stalinisation period. Using Eidenfalk's typology [Eidenfalk 2006: 10], this paper contends that the change had not reached the highest level of change (in terms of scope, domain, and effect of change). Nevertheless, the change was still happened, under a lower classification.

To support this argument, this paper examines the possibility of change from the lowest level to the highest level. The lowest level is, according to Eidenfalk, the stability, in which there was no change at all. This could be disproved by just exploring several things, such as the existence of Soviet economic aid under Khrushchev (which was absent during the era of Stalin) and the visit of Soviet leader under Khrushchev to Indonesia in 1960 (which was also do not exist under Stalin). The second level is the intensification or reduction, in which there was a quantitative change in the policy. Obviously, the increasing economic and military aid proved this argument. The diversification of Soviet policy, ranging from economic aid, military aid, and the political support to Soekarno's policy in West Irian and, albeit grudgingly, Malaysia, could be interpreted as the evidence of a refinement, which is the qualitative instrumental change by maintaining the previous policy instrument. Under Stalin, the foundation of the relations, such as the political support against Dutch during the military aggression of 1948 - 1949, was taken place.

Analysing the next level is more challenging, because the absence of such clear policies during the Stalin's era. The level of reformation (the fourth level) had the prerequisite of a different instrument, and the abolition of the previous policy instrument. Regrettably, the evidence of instruments used by Stalin (other than the normal diplomatic instruments) to accomplish his interests in Indonesia was quite rare. However, one of the recent study of the Soviet archive, conducted by Efimova, showed that Stalin had met with the PKI leader Musso before the event of Madiun rebellion in 1948, and the new leader D.N. Aidit just before Stalin's death. This revelation could be interpreted as the clandestine approach from Stalin to influence Indonesian politics by supporting the overthrow of the legitimate government. However, this claim was rejected by both Efimova's account on Musso [Efimova 2009] and Boden's account on the September 1965 coup, which argued that Moscow did not play any role in supporting the rebellion and the coup [Boden 2007]. Sidel had argued that even though Aidit had met Stalin, 
he never mentioned Stalin's name during the period of Soviet's de-Stalinisation, undoubtedly because of the fear that the Soviet's support towards the PKI will be restrained if he showed his association with Stalin [Sidel 2007]. This lack of evidences can be understood as the elimination of a change in instrument. Therefore, as far as the theoretical framework could be considered, the change in the Soviet foreign policy towards Indonesia during the time of de-Stalinisation could be classified as the refinement. In this types, the new instruments (the military aid and economic aid) was added to the existing diplomatic relations, the political support to the government's policy, and the support towards the Indonesian communist party.

The next issue that is discussed in this paper is the causal factors behind the refinement. As I explain in the theoretical framework, this paper is based on Gustavsson's theory about the two causal factors, namely the domestic and international factors. Taking into account the domestic restructuring that happened in the USSR during the Khrushchev era, as Gehlen had argued, several domestic characteristics could be made [Gehlen 1967]. The first feature was the denunciation of Stalin and Stalinism. The effect of this first condition was, while the Soviet denounced Stalin, it was impossible for the leader of PKI such as Aidit and Njoto to proclaim their meeting with Stalin and that their strategy was derived from Stalin's suggestions. However, this effect was not directly related to the decision of Khrushchev administration to give more aid or political support to Indonesia.

The second feature was the re-emergence of the Party. While Gehlen argued that during the Cuban crisis, the Party played an important part, in the case of Indonesia, there was no evidence that the Party had played similar role [Gehlen 1967: 13]. Quite adversely, the bureaucracy, which had been absent during the later years of Stalin, had played more important role during Stalin's era, in which they managed to delay the recognition of Indonesian independence until 1950. During the Khrushchev era, no evidences had been found regarding the role of the party related to the case of Indonesia.

The third feature, according to Gehlen, was the increasing personal freedom and standard of living. However, even Gehlen himself seemed unable to relate this domestic development to the Soviet foreign policy. Plausibly, the increased wealth of the Soviet could prompt an increasing number of economic aid. Goldmann's argument about the increasing economic aid of the USSR could be used as the evidences of this logic [Goldmann 1965]. However, Goldmann failed to provide evidence about the sources of such amount of money. He focused his analysis more on the effect of the increasing aid towards Soviet's international posture. Nevertheless, the facts that during the stage of economic development in the USSR the amount of international aid was increasing should not be neglected.

The last feature of the domestic de-Stalinisation was the change in the acceptance of Communist theory. The emergence of the "peaceful coexistence" doctrine could be related to this development. However, even during the later years of Stalin, the change in this principle could be demonstrated. As Singh had observed, the changing principles of Soviet foreign policy was actually started during Stalin's era. He had argued that the stalemate condition of the Korean War, the lack of revolutions in the other part of the world (especially the Third World), the rise of China and the probabilities of competi- 
tion between China and USSR, and the beginning of US containment policy in Asia had forced Stalin to rethink his foreign policy, especially regarding the Southeast Asia [Singh 1986: 148].

While the last feature of the domestic de-Stalinisation, namely the change in the acceptance of Communist theory, can be traced back into the era of Stalin, Singh's argument about the change could also be related to the international factors. Consequently, I argue that the international factors played more important role than the domestic deStalinisation. Several specific factors could be highlighted in this section.

The main factor was the contestation between USSR and the United States. This great power rivalry had been one of the most important feature of Cold War international politics, but in this case, the rivalry had set the stage for the changing Soviet policy. The emergence of US's containment policy had been one of the reasons, which forced Stalin to change his policy. The policy of containment, as proposed by George Kennan in 1947, was designed to halt the Soviet from controlling the "Heartland", thereby acknowledging the Heartland theory by Mackinder [Jones 1955]. The strategic areas that should be controlled by the US were called "the Rimland", the concept developed from Spykman's theory of Rimland. Rimland was all the areas encircling the USSR, and one of the most crucial areas, which was still contested after the Cold War, was Asia, particularly Southeast Asia. While Japan had been under the hegemony of the US, China was considered to be under the influence of USSR, the whole region of South Asia and Southeast Asia had just proclaimed their independence. Indonesia was one of the strategic countries in that regards. The increasing presence of the US, especially offering help towards several countries in Asia, including Indonesia, could be seen as the threat towards the USSR. The emergence of the Non-Aligned Movement, initiated by Indonesia during the Asia-Africa Conference in Bandung, 1955, was considered the significant turning points, which shifted the paradigm of the conflict between two-camps (The West and the Communist) towards the competition of the two camps to influence the nonaligned states.

Considered, for once, the Soviet policy to support Indonesian claim towards West Irian and the hesitancy to support the claim on Malaysia. The support in West Irian case could be explained by relating the case to US support to the Dutch. If the USSR supported Indonesia, and the US supported the Dutch, the conflict would turn into a contest between former colonial countries and the newly independence states of Indonesia, into a conflict between imperialist country and the anti-imperialist, in which the USSR would have gain more support from the non-aligned states and the higher international legitimacy. However, in the case of Malaysia, the presence of US and Great Britain was stronger, and instead of a conflict between imperialist and anti-imperialist countries, they would face a conflict between two independent countries (Malaysia and Indonesia) and the full-support of the US on the other side (compared to the hesitancy of US to support the Dutch). As Singh argued, the decision of the US to end the dispute of West Irian in a peaceful manner was differed with the initial goals of the USSR that urged Indonesia to take military action [Singh 1986]. Meanwhile, the hesitancy of the Soviet in supporting Indonesian claims towards Malaysia was proved disastrous, in which Indonesia began to build closer ties with China. 
On another related case, the visit of Army General Nasution to Moscow in 1957 was scheduled after the failed visit to Washington. Washington rejected the Indonesian request of arms deal of $\$ 650 \mathrm{mln}$, on the ground that they feared the weapon would be used in the West Irian. In 1957, the Soviet only gave Nasution \$ $25 \mathrm{mln}$. Several years later, in 1961, Nasution visited Moscow for the second time, to plea for another arms deal. Based on the condition, the USSR had been very welcome to Nasution's request. The arms deal was concluded and Khrushchev had promised the support if Indonesia went to war in the West Irian. The willingness of Khrushchev to help Indonesia over the arms deal, which would be used in the conflict against the Dutch in West Irian, worked as the evidence that the Soviet wanted the war in West Irian to disturb the US deal [Pauker 1961]. While on the other hand, the unwillingness to support Indonesian claims in Malaysia militarily and only offered several grudging support could be attributed to the détente in the US-USSR relations after the Cuban Missile Crisis in 1962.

The other international factors, which also influenced the Soviet policy, was the initial split between USSR and China. As Derkach had argued, the dilemma of the Soviet's policy in Indo-Malaysian dispute was caused by dual factors [Derkach 1965]. On the one hand, the Soviet hesitated because of the presence of the US and Great Britain supporting Malaysia. On the other hand, if the Soviet failed to support Indonesia, the Chinese government could increase their sphere of influence in the Southeast Asia. Indeed, after the West Irian crisis and during the confrontation with Malaysia, the Indonesian government was closer to the Chinese, rather than the Soviet. As Horn suggested, the ongoing economic and military aid from the Soviet to Indonesia had given Soekarno the ammunition to deepen the relations between Indonesia and China [Horn 1975].

The shift in USSR foreign policy towards Indonesia during the de-Stalinisation era could be seen as continuation from the Stalin's policy. This assumption was based on the initial change in Soviet's foreign policy towards Indonesia during the Stalin's era, extending from the support of Indonesian independence in 1945 towards the recognition of RUSI in 1950. Meanwhile, the Soviet policy towards Indonesia during the era of Khrushchev (1953-1964) were characterised by the increasing foreign aid in terms of economic and military aid, and the increasing political support during the West Irian crisis and even during the Malaysian crisis. Using the definition and typology of change from Eidenfalk, this paper concludes that the continuation was indeed a type of foreign policy change. To be more specific, the type of change in this case was the refinement, the third level of change, which was characterised by the combination of old instruments and the new instruments of policy while at the same time having the quantitative and qualitative changes.

Having conclude that the continuation could be classified as a refinement, this paper also concludes that the change was affected more by the international factors rather than the domestic restructuring during de-Stalinisation era. The contestation between USSR and the US was more influential than the political restructuring and domestic upheaval. However, it should be noted that the international condition had also related to the domestic de-Stalinisation, especially through the changes in the acceptance of Com- 
munist theory. The changes in the acceptance, the shifting perception from two-camps contestation into two-camps influencing the neutral world, and the re-emergence of peaceful coexistence coincide with the commencement of US containment policy and the rise of China as the competitor of USSR. The interplay between these international factors and the domestic denunciation of Stalin's principles had prompted the changes in foreign policy. In this sense, even with a low domestic influence and a high international influence, the parallel influence could be interpreted as the two-level game, as promoted by Putnam [Putnam 1988]. Therefore, this paper argues that to understand the changes in foreign policy, the need to comprehend the interplay between these two factors was necessary.

Acknowledgements: The author wishes to thank Dr. Luca Anceschi and Prof. Rebecca Kay for their helpful and constructive feedbacks during the research process. Special thanks also goes to the Erasmus + Scholarship for funding the author to conduct a study about Russia in their Action 1 program.

\section{REFERENCES}

Armstrong, J. A. (1965). The Domestic Roots of Soviet Foreign Policy. International Affairs (Royal Institute of International Affairs), 41(1), 37-47.

Boden, R. (2007). The 'Gestapu' events of 1965 in Indonesia: New evidence from Russian and German archives. Bijdragen tot de Taal-, Land-en Volkenkunde, 163 (4), 507-528.

Boden, R. (2008). Cold War Economics: Soviet Aid to Indonesia. Journal of Cold War Studies, 10 (3), 110-128. DOI: $10.1162 /$ jcws.2008.10.3.110.

Derkach, N. (1965). The Soviet Policy towards Indonesia in the West Irian and the Malaysian Disputes. Asian Survey, 5 (1), 566-571.

Efimova, L. M. (1998). Towards the establishment of diplomatic relations between the USSR and the republic of Indonesia, 1947-48. Indonesia and the Malay World, 26 (76), 184-194.

Efimova, L. M. (2001). New evidence on the establishment of Soviet-Indonesian diplomatic relations (1949-1953). Indonesia and the Malay World, 29 (85), 215-233.

Efimova, L. M. (2009). Did the Soviet Union Instruct Southeast Asian Communists to Revolt? New Russian Evidence on the Calcutta Youth Conference of February 1948. Journal of Southeast Asian Studies, 40 (3), 449-469.

Eidenfalk, J. (2006). Toward a New Model of Foreign Policy Change. Paper presented at Australasian Political Studies Association conference, September, University of Newcastle.

Eidenfalk, J. (2009). A Window of Opportunity? Australian Foreign Policy Change towards East Timor 1998-1999 and Solomons Island 2003. PhD Dissertation, School of History and Politics, Faculty of Arts, University of Wollongong.

Gati, C. (1980). The Stalinist legacy in Soviet foreign policy. In: E. P. Hoffman \& F. J. Fleron. editors. The Conduct of Soviet Foreign Policy. New York: Aldine. p. 644-663.

Gehlen, M. P. (1967). The Politics of Coexistence - Soviet Methods and Motives. Westport, CT: Greenwood.

Goldman, M. I. (1965). A Balance Sheet of Soviet Foreign Aid. Foreign Affairs, 43(2), 349-360.

Gustavsson, J. (1999). How Should We Study Foreign Policy Change. Cooperation and Conflict, 34 (1), $73-95$.

Hermann, C. (1990). Changing course: When government choose to redirect foreign policy. International Studies Quarterly, 34 (1), 3-21.

Horn, R. (1975). Soviet Influence in Southeast Asia: Opportunities and Obstacles. Asian Survey, $15(8), 656-671$.

Jones, S. B. (1955). Global Strategic Views. Geographical Review, 45 (4), 492-508.

Pauker, G. J. (1961). General Nasution's Mission to Moscow. Asian Survey, 1 (1), 13-22. 
Pauker, G. J. (1962). The Soviet Challenge in Indonesia. Foreign Affairs, 40 (4), 612-626.

Pospielovsky, D. (1968). Restalinization or Destalinization? Russian Review, 27 (3), 307-320.

Putnam, R. (1988). Diplomacy and Domestic Politics: The Logic of Two-Level Games. International Organization, 42 (3), 427-460.

Sidel, J. T. (2007). From Russia with Love? A Book Review of Stalin i Indonyeziya: Politika SSSR v otnoshenii Indonyezii v 1945-1953 godakh: Nyeizvyestniye Stranitsiy [Stalin and Indonesia: Soviet Policy towards Indonesia, 1945-1953: Unknown Pages] by L.M. Efimova. Indonesia, $84,161-172$.

Singh, B. (1986). Soviet-Indonesian Relations, 1945-1968. PhD Dissertation, Australian National University.

Tucker, R. D. (1957). The Politics of Soviet De-Stalinization. World Politics, 9 (4), 550 - 578.

Williams, M. C. (1991). New Soviet Policy toward Southeast Asia: Reorientation and Change. Asian Survey, 31(4), 364-377.

Received: 26.01 .2017

For citations: Dharmaputra, Radityo (2017). De-Stalinisation of Soviet Foreign Policy towards Indonesia: Reviewing the Feasibility of the Theory of Foreign Policy Change. Vestnik RUDN. International Relations, 17 (1), 162-174.

About the author: Radityo Dharmaputra - Lecturer of the Department of International Relations, Universitas Airlangga, Indonesia (e-mail: radityo.dharmaputra@fisip.unair.ac.id).

DOI: $10.22363 / 2313-0660-2017-17-1-162-174$

\title{
ДЕСТАЛИНИЗАЦИЯ ВНЕШНЕЙ ПОЛИТИКИ СССР ПО ОТНОШЕНИЮ К ИНДОНЕЗИИ В РАМКАХ ТЕОРИИ ИЗМЕНЕНИЯ ВНЕШНЕЙ ПОЛИТИКИ
}

\author{
Радитио Дармапутра \\ Университет Аирланга, Сурабайа, Индонезия
}

В рамках данной статьи анализируются изменения политики Советского Союза по отношению к Индонезии в период правления Иосифа Сталина и Никиты Хрущева сквозь призму современной теории изменения внешней политики.

Автор статьи поддерживает точку зрения Патнэма, что в случае каких-либо изменений причины, вероятно, следует искать во взаимодействии внутренних и международных факторов. Данное исследование совершенствует понимание, что внутриполитический процесс десталинизации в период Хрущева был не единственным фактором, который мог повлиять на внешнюю политику СССР. На примере Индонезии как развивающейся страны автор демонстрирует, что оба набора факторов влияли на изменение политики. Тем не менее, в работе утверждается, что системное состояние холодной войны, а именно борьба между США и СССР, оказывало большее влияние, чем внутренняя обстановка. Данная работа способствует более глубокому пониманию советско-индонезийских отношений, влияния десталинизации на внешнюю политику СССР, а также раскрывает возможность применения современной теории изменения внешней политики в рамках конкретного исторического примера.

Ключевые слова: десталинизация, советская внешняя политика, теория изменения внешней политики, Индонезия, внутренние факторы, международные факторы 
Благодарность: Автор выражает благодарность доктору Луке Анчески и профессору Ребекке Кей за их полезные и конструктивные комментарии в процессе исследования. Отдельное спасибо Erasmus + Scholarship за предоставление финансирования проведения исследования о России в рамках своей программы Action 1.

Для цитирования: Dharmaputra Radityo. De-Stalinisation of Soviet Foreign Policy towards Indonesia: Reviewing the Feasibility of the Theory of Foreign Policy Change // Вестник Российского университета дружбы народов. Серия: Международные отношения. 2017. Т. 17. № 1. С. 162-174.

Сведения об авторе: Радитио Дармапутра - лектор Департамента международных отношений, Университет Аирланга, Индонезия (e-mail: radityo.dharmaputra@fisip.unair.ac.id).

(C) Radityo Dharmaputra, 2017 